\title{
APLIKASI PELAYANAN ADMINISTRASI DESA KARANG DIMA BERBASIS WEB
}

\author{
Indra Jaya Putra ${ }^{1}$, Muhammad Hidayatullah ${ }^{2}$, Aswin Tri Juniarta ${ }^{3}$ \\ ${ }^{1.3}$ Program Studi Informatika, Fakultas Teknik, Universitas Teknologi Sumbawa \\ ${ }^{2}$ Program Studi Teknik Elektro, Fakultas Teknik, Universitas Teknologi Sumbawa \\ 1.2.3 Jl. Raya Olat Maras BatuAlang-Sumbawa Besar \\ 1. indrajayaputa42@gmail.com, ${ }^{2}$ muhammad.hidayatullah@uts.ac.id, 3 aswin.try.juniarta@uts.ac.id
}

\begin{abstract}
Abstraksi
Saat ini teknologi sangat berperan penting dalam semua bidang, salah satunya dalam bidang Administrasi. Desa Karang Dima merupakan salah satu desa yang berada di Kecamatan Labuhan Badas, mempunyai luas wilayah 32,14 pada tahun 2018. Desa Karang Dima mempunyai 2.047 kepala keluarga dengan jumlah penduduk 6.951 jiwa.Penelitian ini bertujuan menyelsaikan masalah yang ada dalam Pelayanan Administrasi di Desa Karang Dima dengan merancang dan membangun Aplikasi Pelayanan Administrasi Penduduk. Aplikasi ini fokus pada pelayanan Administrasi (pembuatan surat) agar proses yang dilakukan lebih mudah dan cepat sehingga dapat memuaskan masyarakat dalam pelayanan administrasi oleh staf Desa Karang Dima.

Aplikasi berbasis WEB dikembangkan menggunakan bahasa pemrograman PHP dengan menggunakan Mysql sebagai database. Metode pengembangan perangkat lunak menggunakan metode Waterfall. Pengujian perangkat lunak dilakukan melalui pengujian Black-Box. Hasil akhir dari penelitian ini adalahAplikasi Pelayanan Administrasi Desa Karang Dima Berbasis Web yang dapat membantu Admin Desa dalam memberikan pelayanan administrasi kepada warga desa secara cepat dan tepat.
\end{abstract}

Kata Kunci: Aplikasi, Administrasi, Karang Dima, Waterfall, Black-box.

\begin{abstract}
Nowdays, technology has an important role in all aspects, particularly in administrative matter. Karang Dima village is part of Labuhan Badas county, it has area of 32.14 ha in 2018.This village has 2,047 family heads with total population about 6,951 people. This research is aimed to seek solution in term of public administrative services by designing and developing a public administrative service application.This application focuses on administrative services (obtaining an official letter) in order to speed up its process to satisfy village society by all officers of the village.

A Web application is developed using PHP program with MySQL database. The software development uses Waterfall method.The result from this research is an web based application of administrative service from Karang Dima village to assist the administrator providing administrative service briefly and accurately to society.
\end{abstract}

Keywords: Application, Administration, Karang Dima, Waterfall, Black-box. 


\section{PENDAHULUAN}

\subsection{Latar Belakang}

Desa Karang Dima merupakan salah satu desa yang berada di Kecamatan Labuhan Badas, mempunyai luas wilayah 32,14 pada tahun 2018 . Desa Karang Dima mempunyai 2.047 kepala keluarga dengan jumlah penduduk 6.951 jiwa. Mayoritas penduduk Desa Karang Dima adalah petani dengan komoditas terbanyak yaitu jagung, padi, dan kacang hijau. Dalam setiap tahun, jumlah penduduk Desa Karang Dima meningkat.

Berdasarkan hasil perbincangan dengan Pak Ade selaku admin di Kantor Desa Karang Dima pada tanggal 23 maret 2019 bahwa Kantor Desa Karang Dima belum memiliki alternatif lain dalam menyelesaikan masalah pelayanan Administrasi yang belum dapat memuaskan masyarakat dalam pelayanannya yang dikarenakan sumber daya manusianya yang masih kurang dan kemampuan akan teknologi masih minim. Sehingga banyak terdapat keluhan dari masyarakat akan pelayanan Administrasi di Desa Karang Dima yang dikarenakan antrian yang panjang, proses yang amat rumit, dan berkas syarat yang banyak yang harus di siapkan sehingga memakan waktu berharihari dalam proses pembuatan surat.

Berdasarkan hasil perbincangan dengan Admin Kantor Desa Karang Dima yang telah penulis paparkan di atas, penulis mempunyai solusi dengan harapan dapat menyelsaikan masalah yang ada dalam Pelayanan Administrasi di Desa Karang Dima. Solusi yang penulis usulkan adalah merancang dan membangun Aplikasi Pelayanan Administrasi Penduduk Berbasis WEB. Aplikasi ini merupakan aplikasi yang hanya berfokus pada pelayanan Administrasi (pembuatan surat) agar proses yang dilakukan lebih mudah dan cepat sehingga dapat memuaskan masyarakat dalam pelayanan administrai yang di lakukan oleh staf Desa Karang Dima dan menyelsaikan masalah minimnya pengetahuan akan teknologi dari Sumber Daya Manusia (SDM) di dalam Kantor Desa Karang Dima

\subsection{Rumusan Masalah}

Berdasarkan latar belakang di atas, rumusan masalah yang timbul adalah bagaimana caranya membangun sistem pelayanan Administrasi agar lebih mudah dengan aplikasi sehingga masyarakat memperoleh pelayanan Administrasi yang cepat dan tepat dari pemerintah desa ?

\subsection{Batasan Masalah}

Adapun ruang lingkup masalah dari Aplikasi Pelayanan Administrasi Penduduk Berbasis WEB adalah sebagai berikut :

1. aplikasi yang akan di buat merupakan aplikasi pelayanany Administrasi yang meliputi pembuatan surat, mengelolah data penduduk, mutasi penduduk masuk, pindah, lahir dan meninggal, mengelolah surat-surat keluar yang dijadikan laporan akhir,

2. aplikasi hanya dapat di akses oleh admin Kantor Desa Karang Dima.

Aplikasi Pelayanan Administrasi Penduduk ini di buat dengan menggunakan Bahasa Pemrograman PHP, dan Mysql.

\subsection{Tujuan Penelitian}

Selain dari rumusan masalah dan batasan masalah,, penelitian ini mempunyai tujuan sehingga dapat member solisi dalam rumusan masalah yang ada. Tujuan dari penelitian ini adalah merancang dan membangun sebuah Aplikasi Pelayanan Administrasi Penduduk Berbasis Web di Desa Karang Dima, sehingga dapat mempermuda staf di Desa Karang Dima dalam melayani Administrasi masyarakat. Sehingga masyarakat dapat merasa puas atas pelayanan dari desa dan selain mempermudah masyarakat dan staf desa, Aplikasi ini bertujuan menyelsaikan masalah yang ada akan minimnya Sumber Daya Manusia dan minimnya akan pengetahuan teknologi perangkat desa.

\subsection{Manfaat Penelitian}

Adapun manfaat dari penelitian ini dibagi menjadi dua yaitu manfaat praktis dan manfaat teoretis.

\subsubsection{Manfaat Teoris}

1. Hasil penelitian ini diharapkan dapat menambah pengetahuan bagi peneliti. Staf Desa dan Admin Desa Karang Dima.

2. Hasil penelitian ini diharapkan dapat dijadikan pedoman bagi perangkat desa dalam menjalankan tugas dan kewajibannya untuk melayani masyarakat desa dengan aplikasi pelayanan ini.

\subsubsection{Manfaat Praktis}

Memberikan pengetahuan serta pengalaman bagi peneliti mengenai media pelayanan administrasi desa dan meningkatkan pengetahuan bagi staf desa yang masih minim akan teknologi.

\subsection{Sistematika Penulisan}

Untuk member gambaran tentang penelitian ini, maka disusunlah suatu sistematika penulisan berisi tentang materi yang dibahas disetiap bab pembahasan. 


\section{LANDASAN TEORI}

\subsection{Tinjauan Pustaka}

Setelah melakukan observasi terhadap beberapa penelitian lainnya terkait dengan penelitian yang penulis lakukan, penulis menemukan beberapa penelitian yang mempunyai keterkaitan dengan proses yang penulis lakukan.

Penelitian pertama dilakukan oleh Dodik Kurniawan (2017) dengan judul "Rancang Bangun Sistem Informasi Pelayanan Administrasi Penduduk pada Kantor Desa Kasreman Kecamatan Kandangan Kabupaten Kediri”. Tujuan dari penelitian ini adalah membahas tentang proses dan tampilan dalam aplikasi sehingga dapat memberikan gambaran bahwa proses yang harus dilakukan seperti apa dan bagaimananya. Hasil penelitian menunjukan bahwa aplikasi pelayanan Administrasi desa telah dapat membantu proses pengurusan pembuatan surat keterangan dan lebih bermanfaat bagi desa terutama khususnya staf desa yang bertugas di dalam pelayanan Administrasi desa sampai saat ini.metode yang digunakan dalam penelitian ini adalah menggunakan metode Multimedia Development life cycle (MDLC) yang terdiri dari enam tahap yaitu pengonsepan, perancangan, pengumpulan materi, pembuatan, pengujian, dan pendistribusian.

Berdasarkan penelitian di atas penulis bertujuan menambahkan beberapa fitur yang masih belum lengkap dalam penelitian di atas seperti fitur penyediaan informasi syarat memproses surat-surat keterangan, fitur informasi hasil penghasilan desa dan fitur laporan surat yang telah di proses yang dapat di jadikan laporan akhir dari bidang kependudukan.

\section{$2.2 \quad$ Dasar Teori}

Adapun dasar teori yang mendukung dalam pembuatan laporan ini sebagai berikut:

\subsubsection{Aplikasi}

Menurut Muhammad Fathul Mubarak (2017), aplikasi adalah program siap pakai yang dapat digunakan untuk menjalankan perintah" dari pengguna aplikasi tersebut dengan tujuan mendapatkan hasil yang lebih akurat sesuai dengan tujuan pembuatan apliaksi tersebut, Aplikasi mempunyai arti yaitu pemecahan masalah yang menggunakan salah satu teknik pemrosesan data aplikasi yang biasanya berpacu pada sebuah komputasi yang diinginkan atau diharapkan maupun pemrosesan data yang dihharapkan.

Kurniawan (2012) aplikasi adalah suatu bagian dari perangkat lunak yang dapat digunakan untuk menyelsaikan masalah-masalah yang khusus yang dihadapi User dengan menggunakan kemampuan computer. jadi aplikasi adalah bentuk program yang digunakan untuk mempermudah pengguna untuk menjalankan suatu perintah dengan mudah dan lebih akurat sesuai dengan yang diharapkan.

\subsubsection{Unified Modeling Language (UML)}

Menurut Rosa A. S. M. shalahuddin, (2018:137). Unified Modeling Language adalah bahasa visual untuk pemodelan dan komunikasi mengenai sebuah sistem dengan menggunakan diagram dan teks-teks pendukung.

Pemodelan $U M L$ menggunakan diagram sebagai berikut:

\section{Use Case Diagram}

Diagram Use Case adalah pemodelan untuk kelakukan (behavior) sistem informasi yang akan dibuat. Use Case mendeskripsikan sebuah intraksi antara satu atau lebih actor dengan sistem informasi yang akan dibuat. Secara kasar Use Case digunakan untuk mengetahui fungsi apa saja yang ada didalam sebuah sistem informasi dan siapa saja yang berhak menggunakan fungsi-fungsi itu.

2. Activity Diagram

Activity Diagram merupakan workflow (aliran kerja) atau aktifitas dari sebuah sistem atau proses bisnis atau menu yang ada pada perangkat lunak.

3. Squence Diagram

Sequence Diagram adalah menggambarkan kelakuan objek pada use case dengan mendeskripsikan waktu hidup objek dan message yang dikirimkan dan diterima antar objek.

4. Class Diagram

Class Diagram adalah menggambarkan struktur sistem dari segi pendefinisian kelas-kelas yang akan dibuat untuk membangun sistem.

\subsubsection{Waterfall}

Menurut Rosa A.S M. Shalahuddin (2018:28). Waterfall sering juga disebut model sekuensial linier (sequentian linear) atau alur hidup klasik (classic life cycle). Model air terjun menyediakan pendekatan alur hidup perangkat lunak secara sekuensial atau terurut dimulai dari analisis, desain, pengkodean, pengujian, dan tahap pendukung (support).

\subsubsection{Pengujian Black Box}

Pengujian Black Box menurut Mustaqbal, Firdausdan Rahmadi (2015: 34). Metode pengujian 
black box adalah metode pengujian yang berfokus pada spesifikasi fungsional sebuah perangkat lunak (Mustaqbal, Firdaus dan Rahmadi, 2015: 34).

Black box testing umumnya bertujuan untuk membuktikan hal-hal berikut :

a. Fungsi yang tidak benar atau tidak ada.

b. Kesalahan antar muka (interface eror).

c. Kesalahan pada struktur data dan akses basis data.

d. Kesalahan performansi.

e. Kesalahan inisialisasi dan terminasi. Adapun perbandingan antara pengujian black box dengan pengujian White Box yaitu sebagai berikut:

Tabel 2.1 Pengujian Black Box dan White Box

\begin{tabular}{|c|c|c|}
\hline $\begin{array}{l}\text { Tahapan } \\
\text { Perbandi } \\
\text { ngan }\end{array}$ & Black Box & White Box \\
\hline Pengertian & $\begin{array}{l}\text { Pengujian } \\
\text { berorientasi } \\
\text { pada detail } \\
\text { aplikasi yang } \\
\text { meliputi } \\
\text { tampilan, } \\
\text { fungsi-fungsi } \\
\text { yang ada, dan } \\
\text { kesesuaian alur } \\
\text { fungsi dengan } \\
\text { bisnis proses } \\
\text { yang } \\
\text { diinginkan. } \\
\text { Pengujian } \\
\text { dilakukan oleh } \\
\text { tim penguji } \\
\text { yang dimana } \\
\text { selama proses } \\
\text { pengujian tidak } \\
\text { menyentuh } \\
\text { kode program, } \\
\text { karena yang } \\
\text { diuji adalah } \\
\text { bagian luar dari } \\
\text { aplikasi. }\end{array}$ & $\begin{array}{l}\text { Pengujian yang } \\
\text { didasarkan pada } \\
\text { detail prosedur } \\
\text { dan alur logika } \\
\text { kode program. } \\
\text { Pada kegiatan } \\
\text { whitebox } \\
\text { testing, tester } \\
\text { melihat source } \\
\text { code program } \\
\text { dan } \\
\text { menemukan } \\
\text { bugs dari kode } \\
\text { program yang } \\
\text { diuji. Intinya } \\
\text { whitebox testing } \\
\text { adalah } \\
\text { pengujian yang } \\
\text { dilakukan } \\
\text { sampai kepada } \\
\text { detail } \\
\text { pengecekan } \\
\text { kode program. }\end{array}$ \\
\hline $\begin{array}{l}\text { Kegiatan } \\
\text { pengujian }\end{array}$ & $\begin{array}{l}\text { a. Membuat test } \\
\text { case untuk } \\
\text { menguji } \\
\text { fungsi-fungsi } \\
\text { dari aplikasi } \\
\text { yang diuji. } \\
\text { b. Membuat test } \\
\text { case untuk } \\
\text { menguji } \\
\text { kesesuaian } \\
\text { alur kerja } \\
\text { suatu fungsi } \\
\text { pada aplikasi } \\
\text { dengan } \\
\text { requirement } \\
\text { yang } \\
\text { dibutuhkan. }\end{array}$ & $\begin{array}{lr}\text { Melihat } & \text { kode } \\
\text { programmembu } \\
\text { at test case } \\
\text { untuk mencari } \\
\text { kesalahan atau } \\
\text { bugs atau } & \text { error } \\
\text { dari } & \text { kode } \\
\text { program yang } & \text { dibuat oleh } \\
\text { programmer }\end{array}$ \\
\hline
\end{tabular}

\begin{tabular}{|l|l|l|}
\hline c. Mencaari bug \\
atau error \\
pada interface \\
aplikasi
\end{tabular} \mid

\section{METODOLOGI PENELITIAN}

\subsection{Metode Penelitian}

Tahap-tahap yang dilakukan dalam pengumpulan data untuk merancang dan membangun Aplikasi Pelayanan Administrasi ini dapat di gambarkan pada bagan alur sebagai berikut :

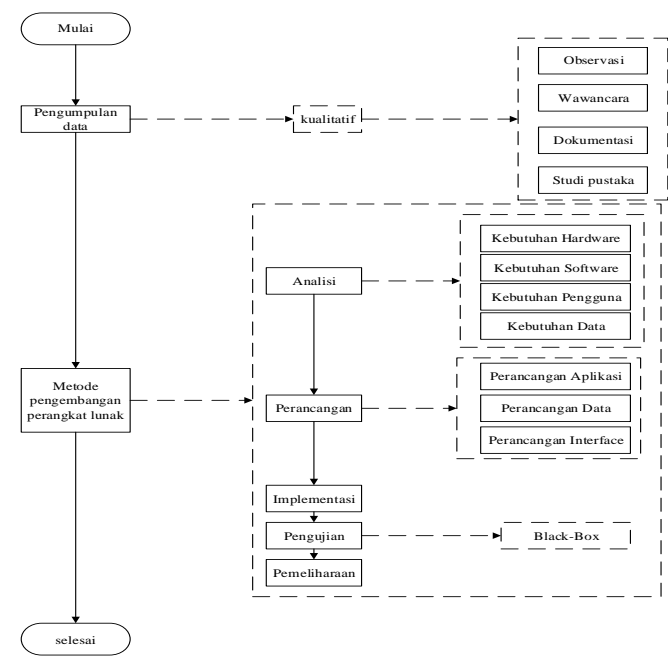

Gambar 3.1 Alur metode penelitian

\subsubsection{Metode Pengumpulan Data}

Adapun prosedur pengumpulan data diantaranya menggunakan teknik berikut:

a. Observasi

b. Wawancara

c. Dokumentasi

d. Studi Pustaka

\subsubsection{Metode Pengembangan Perangkat Lunak}

Dalam pembuatan suatu aplikasi tentunya memiliki beberapa metode dalam pengembangan perangkat lunak. Adapun metode dalam pengmbangan perangkat lunak yang digunakan dalam Pembuatan Aplikasi Pelayanan Administrasi Desa Karang Dima Berbasis WEB ini adalah metode waterfall. Dengan metode waterfall ini pengembangan aplikasi dapat dikerjakan secara terstruktur dan dalam proses pengerjaannya dilakukankan secara bertahap, dimulai spesifikasi kebutuhan pengguna lalu berlanjut ke tahap-tahap perancangan, permodelan, kontruksi, serta penyerahan aplikasi ke tempat penelitian. 


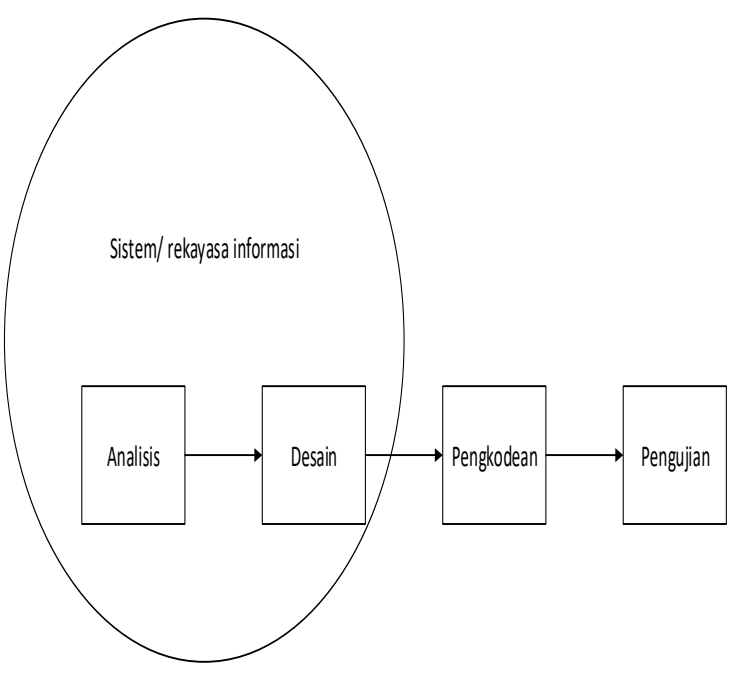

Gambar 3.2 Metode Waterfall

\subsection{Alat Dan Bahan Penelitian}

Alat penelitian yang digunakan dibagi menjadi tiga yaitu komponen perangkat keras, perangkat lunak dan pengguna sebagai pendukung penelitian yang dilakukan, alat ini yang akan dijadikan sebagai alat pengolahan data dan pembuatan aplikasi yang akan dibuat.

a. Kebutuhan perangkat keras

b. Kebutuhan perangkat lunak

c. Kebutuhan data

\section{HASIL DAN PEMBAHASAN}

\subsection{Hasil Pengumpulan Data}

Hasil dari pengumpulan data yang telah dilakukan dalam penelitian ini adalah sebagai berikut:

\subsubsection{Observasi}

Setelah melakukan observasi pada kantor Desa Karang Dima Kecamatan Labuhan Badas, maka kantor desa menyetujui dijadikan objek penelitian guna membangun sebuah Aplikasi Pelayanan Administrasi Desa untuk mendukung dan membantu staf desa dalam pengolahan data dan pembuatan surat.

\subsubsection{Wawancara}

Pada tahap wawancara dilakukan dengan wawancara langsung dan memberikan pertanyaan langsung kepada pihak kantor desa yaitu bapak Ade Setyawan selaku admin atau staf desa yang membuat surat-surat yang di keluarkan oleh desa. Dari wawancara tersebut diketahui bahwa pihak desa belum memiliki aplikasi dan masih dilakukan secara manual, sehingga penelitian ini diharapkan dapat membantu pihak desa dalam mengolah data dan membuat surat menjadi lebih mudah dan efisiensi.

\subsubsection{Dokumentasi}

Pada tahap dokumentasi ini, peneliti mengumpulkan dokumen-dokumen yang dapat mendukung dalam pembuatan aplikasi seperti suratsurat yang dibuat oleh staf desa dank $\mathrm{k}$ yang dijadikan sampel sebagai data pendukung aplikasi.

\subsubsection{Study Pustaka}

Pada tahap studi pustaka ini peneliti mengumpulkan data atau referensi yang dapat mendukung pembuatan apliaksi dan mecari informasi mengenai aplikasi pelayanan administrasi di internet.

\subsection{Hasil Analisis Kebutuhan}

Adapun hassil dari analisis kebutuhan dalam membangun Aplikasi Pelayanan Administrasi Desa Karang Dima Berbasis Web adalah sebagai berikut:

\subsubsection{Kebutuhan Perangkat Keras}

Adapun perangkat keras yang digunakan untuk pembuatan Aplikaasi Pelayanan Administrasi Desa Berbasis Web adalah sebagai berikut:

Tabel 4.1 Kebutuhan perangkat keras

\begin{tabular}{|l|l|}
\hline Nama Perangkat & Spesifikasi \\
\hline Laptop & Memori (RAM) 2.00 GB \\
\hline & Processor intel inside \\
\hline & Harrdisk \\
\hline
\end{tabular}

\subsubsection{Kebutuhan Perangkat Lunak}

Adapun kebutuhan perangkat lunak yang digunakan dalam rancang bangun Aplikasi Pelayanan Administrasi Desa Karang Dima Berbasis Web ini adalah sebagai berikut:

Tabel 4.2 Kebutuhan Perangkat Lunak

\begin{tabular}{|c|c|c|}
\hline No & $\begin{array}{l}\text { Perangkat } \\
\text { Lunak }\end{array}$ & Keterangan \\
\hline 1. & $\begin{array}{ll}\text { Windows } & 7 \\
\text { Professional }\end{array}$ & $\begin{array}{lr}\text { Digunakan } & \text { untuk } \\
\text { menjalankan aplikasi } \\
\text { yang dibuat oleh } \\
\text { pengembang. }\end{array}$ \\
\hline 2. & $\begin{array}{l}\text { Mysql } \\
\text { connector versi } \\
6.9 .8\end{array}$ & $\begin{array}{lr}\text { Digunakan } & \text { untuk } \\
\text { mengkoneksikan } & \\
\text { Database } & \text { dengan } \\
\text { pemrograman } & \text { Java } \\
\text { yang dibuat } & \text { dengan } \\
\text { Netbeans. } & \end{array}$ \\
\hline 3. & $\begin{array}{l}\text { Microsoft Visio } \\
2007\end{array}$ & $\begin{array}{lr}\text { Digunakan } & \text { untuk } \\
\text { perancangan } & \text { Sistem } \\
\text { seperti pembuatan DFD }\end{array}$ \\
\hline
\end{tabular}




\begin{tabular}{|l|l|l|}
\hline & & dan flowchart \\
\hline 4. & Xampp & $\begin{array}{l}\text { Menjadi server yang } \\
\text { digunakan untuk } \\
\text { mengakses MySQL. }\end{array}$ \\
\hline 5. & MySQL & $\begin{array}{l}\text { Digunakan untuk dalam } \\
\text { mengelola database } \\
\text { seperti menambahkan, } \\
\text { mengubah, dan } \\
\text { menghapus data. pebagai text }\end{array}$ \\
\hline 6 & Sublime & $\begin{array}{l}\text { Digunakan sebraman } \\
\text { editor pemrogram } \\
\text { dalam pembuatan } \\
\text { aplikasi. }\end{array}$ \\
\hline
\end{tabular}

\subsubsection{Kebutuhan Data}

Adapun kebutuhan data yang dibutuhkan dalam mengelola data dan pembuatan surat pada Kantoe Desa Karang Dima ini yaitu data penduduk dan surat-surat yang dapat dibuat di Desa Karang Dima

\subsection{Perancangan Aplikasi}

Adapun Squence diagram dari Aplikasi Pelayanan Administrasi Desa Karang Dima Berbasis Web adalah sebagai berikut:

\subsubsection{Use Case Diagram}

Adapun Squence diagram dari Aplikasi Pelayanan Administrasi Desa Karang Dima Berbasis Web adalah sebagai berikut:

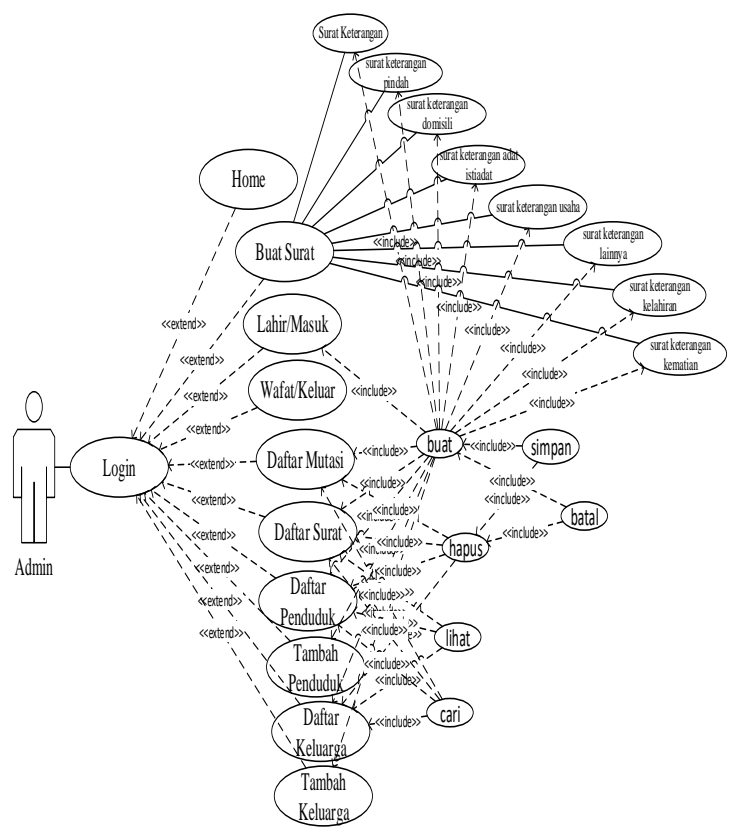

Gambar 4.1 Use Case Diagram

Pada use case diagram diatas, aplikasi memberikan akses hanya kepada 1 aktor yaitu admin. Admin dapat mengakses seperti login, home, buat surat, lahir/masuk, wafat/keluar, daftar mutasi, daftar surat, daftar penduduk, tambah penduduk, daftar keluarga, dan tambah keluarga. Dan didalam menu buat surat terdapat sub menu yaitu surat keterangan, surat keterangan pindah, surat keterangan adat istiadat, surat keterangan domisili, surat keterangan usaha, surat keterangan kematian, surat keterangan kelahiran, surat keterangan lainnya. Adapun beberapa aksi didalamnya yaitu, buat, hapus, lihat, cari.

\subsubsection{Activity Diagram}

Adapun activity diagram pada Aplikasi Pelayanan Administrasi Desa Karang Dima Berbasis Web adalah sebagai berikut:

a. Activity Diagram Login

Adapun activity diagram dari halaman login adalah sebagai berikut:

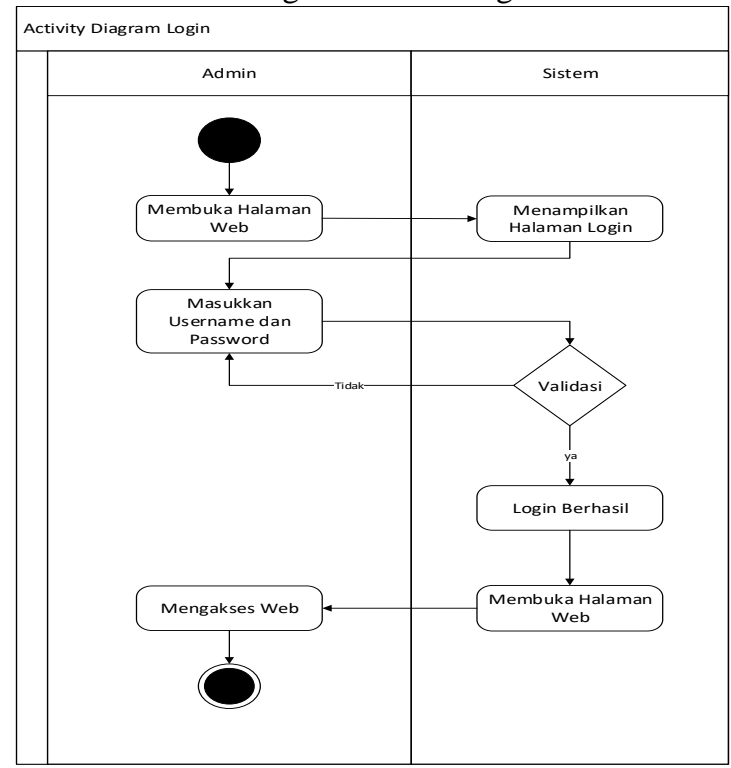

Gambar 4.2 Activity Diagram Login

Proses dimulai yaitu pada saat user membuka tampilan masuk atau login maka aplikasi akan menampilkan tampilan login, lalu user dapat memasukkan username dan password untuk login. Selanjutnya dilakukan validasi data yang dimasukkan, jika benar maka akan menampilkan menu utama aplikasi dan jika salah maka otomatis akan mengulang untuk memasukkan username dan password.

b. Activity diagram buat surat

Activity diagram untuk melakukan pembuatan surat adalah sebagai berikut: 


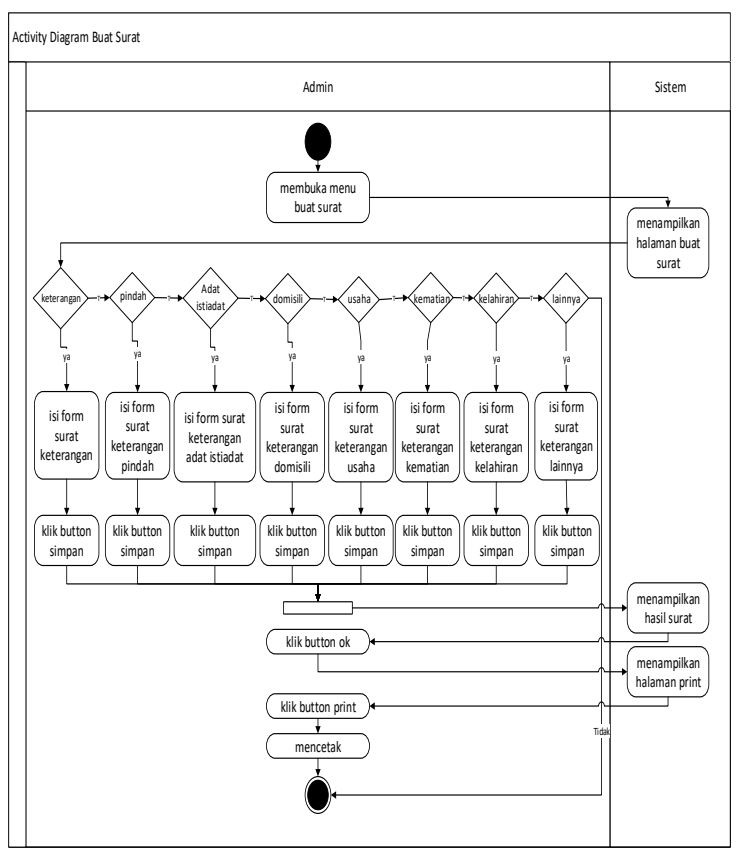

Gambar 4.3 Activity Diagram Buat Surat

Pada proses ini diawali dengan admin membuka menu buat surat maka sistem akan menampilkan menu buat surat, admin memilih jenis surat yang akan dibuat, dalam proses jenis surat ini terdapat proses yang sama sehingga dapat dijelaskan dengan mengambil 1 (satu) sampel dalam penjelasannya. Ketika admin sudah memilih jenis surat maka sistem akan menampilkan form surat yang harus diisi, setelah form surat terisi maka admin klik button simpan kemudian sistem akan menampilkan hasil pembuatatan surat lalu admin klik button oke, kemudian sistem akan menampilkan halaman print, lalu admin klik button print, surat berhasil dicetak.

\subsubsection{Squence Diagram}

Squence Diagram menjelaskan permodelan sistem yang akan dibangun untuk menggambarkan interkasi antara obyek yang telah disusun dan merupakan tahap proses dari usecase diagram dan activity diagram.

a. Squence diagram halaman login

Berikut adalah gambar dari squance diagram halaman login pada aplikasi pelayanan administrasi desa karang dima berbasis web :

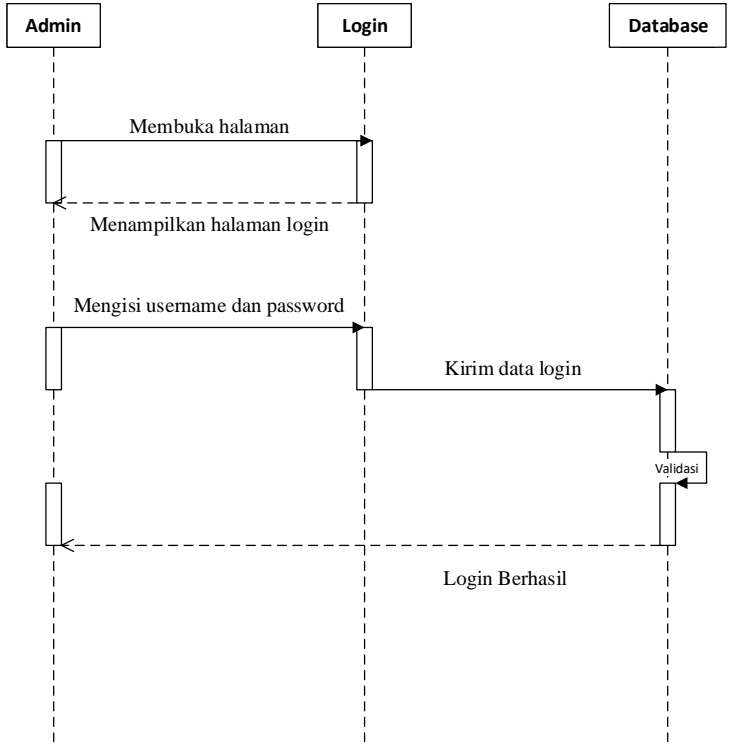

Gambar 4.4 Squence diagram halaman login

Proses dimulai yaitu pada saat user membuka tampilan login, maka sistem akan menampilkan tampilan login lalu user dapat memasukkan username dan password untuk dan dilakukan validasi agar dapat mengakses aplikasi.

b. Squence diagram halaman buat surat

Dalam squence diagram dalam pembuatan surat ini mempunyai beberapa proses didalamnya seperti banyaknya jenis surat yang dibuat sebagai berikut :

1. Squence diagram halaman buat surat keterangan

Berikut adalah gambar dari squance diagram halaman buat surat keterangan pada aplikasi pelayanan administrasi desa karang dima berbasis web :

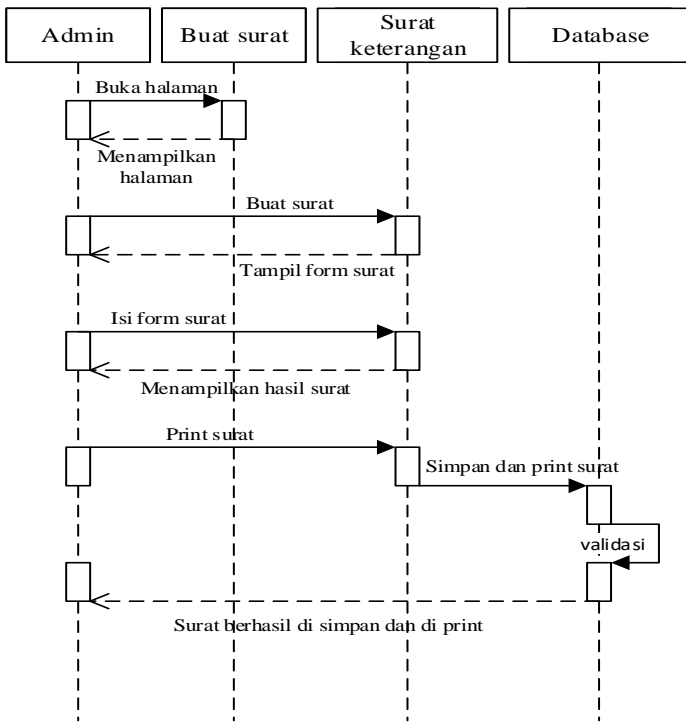

Gambar 4.5 Squence Diagram Halaman Buat Surat Keterangan 
Proses dimulai pada saat admin membuka tampilan buat surat kemudian sistem menampilkan halaman buat surat, kemudian admin membuka halaman buat surat keterangan, sistem menampilkan form surat yang harus diis, lalu admin mengisi form, kemudian sistem menampilkan hasil surat yang dibuat, kemudian admin print surat dan sistem melakukan validasi data disimpan dan di print jika data benar maka data dapat diprint.

2. Squence diagram halaman buat surat keterangan pindah.

Berikut adalah gambar dari squance diagram halaman buat surat keterangan pindah pada aplikasi pelayanan administrasi desa karang dima berbasis web :

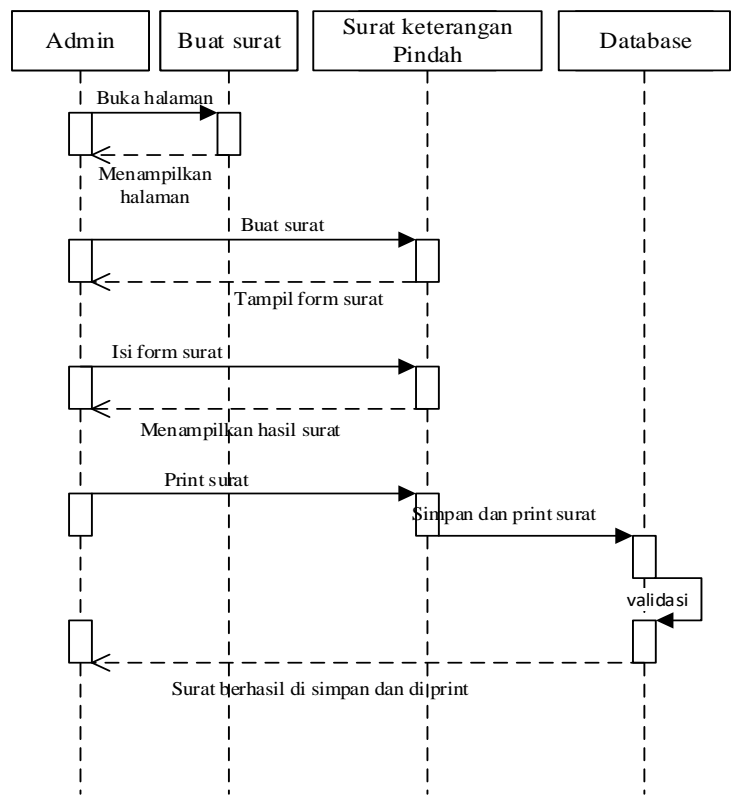

\section{Gambar 4.6 Squence Diagram Halaman Buat Surat Keterangan Pindah}

Proses dimulai pada saat admin membuka tampilan buat surat kemudian sistem menampilkan halaman buat surat, kemudian admin membuka halaman buat surat keterangan pindah, sistem menampilkan form surat yang harus diis, lalu admin mengisi form, kemudian sistem menampilkan hasil surat yang dibuat, kemudian admin print surat dan sistem melakukan validasi data disimpan dan di print jika data benar maka data dapat diprint.

\subsubsection{Class Diagram}

Class diagram adalah diagram yang digunakan untuk menampilkan beberapa kelas yang ada dalam sistem perangkat lunak yang akan dikembangkan. Class diagram menunjukan hubungan antar class dalam sistem yang sedang dibangun dan bagaimana mereka saling berkolaborasi untuk mencapai suatu tujuan.

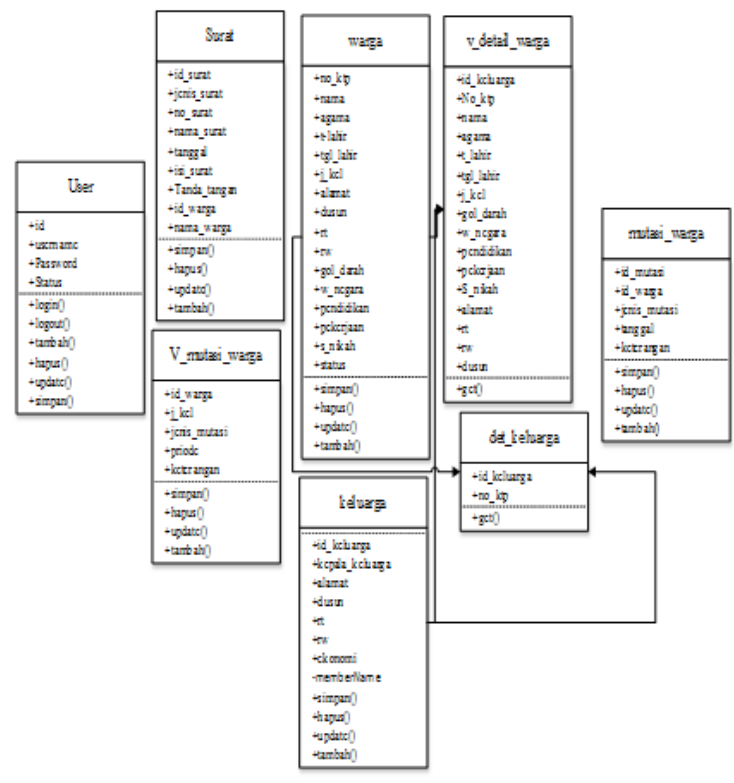

Gambar 4.7 Class Diagram

\subsubsection{Relasi Antar Tabel}

Relasi antar tabel adalah suatu gambaran tentang hubungan tabel yang ada didalam database yang dimana setiap tabel ada yang mempunyai hubungan dengan tabel lainnya.

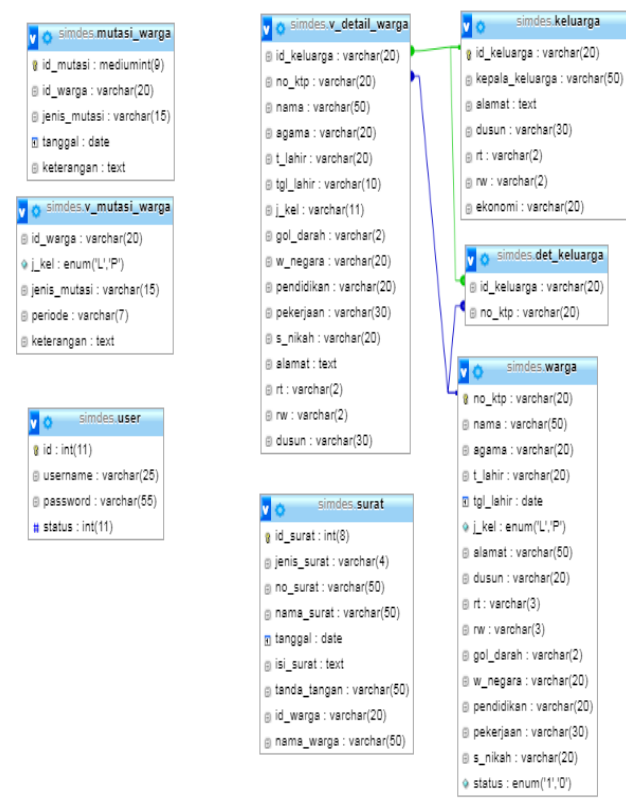

\section{Gambar 4.8 Relasi antar tabel}

\subsection{Perancangan Interface}

Rancangan user interface merupakan suatu gambaran tentang tampilan aplikasi yang akan 
dibangun. Berikut merupakan penjabaran tentang tampilan interface dari Aplikasi Pelayanan Administrasi Penduduk Desa Karang Dima.

\subsubsection{Rancangan Halaman Login}

Adapun Rancangan halaman login adalah sebagai berikut:

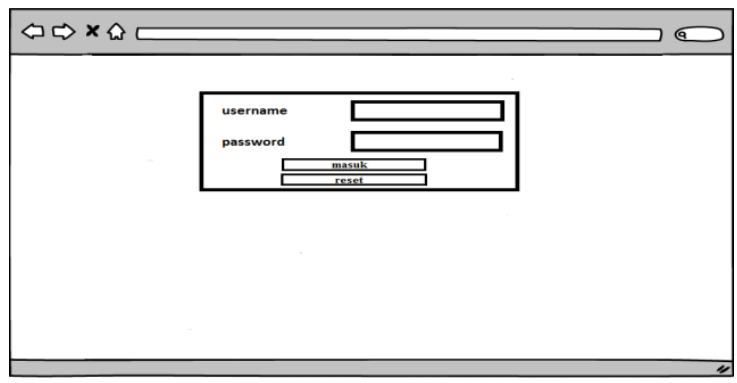

Gambar 4.9 Rancang Halaman Login.

Gamabar diatas merupakan rancangan halaman login, pada form diatas terdapat textboxusername dan password yang berfungsi sebagai tempat inputan akun yang sudah terdaftar sebelumnya atau akun yang sudah dibuat. Dengan memasukkan username dan password login maka admin dapat mengakses semua halaman dan fiturfitur yang terdapat didalam aplikasi.

\subsubsection{Rancangan Halaman Buat Surat.}

Adapun Rancangan halaman Buat Surat adalah sebagai berikut:

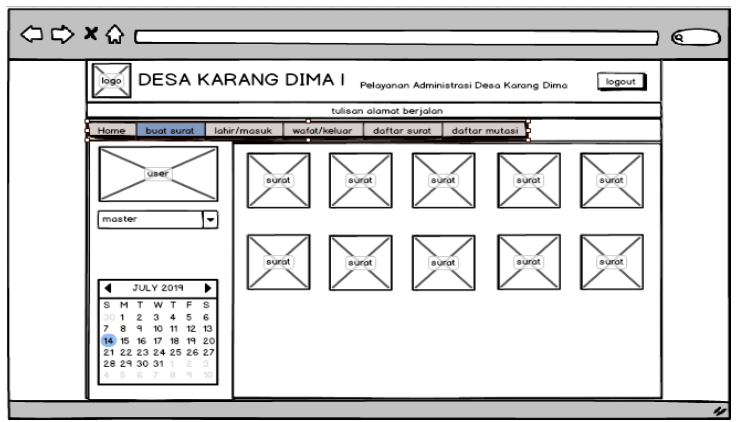

Gambar 4.10 Rancang Halaman Buat Surat.

Pada gambar perancangan di atas merupakan perancangan halaman membuat surat dimana pada saat ingin membuat surat, kita harus memilih jenis surat yang ingin di buat kemudian diberikan form untuk informasi yang dibuat dalam surat sehingga surat dapat dibuat dan dicetak.

\subsection{Implementasi Interface}

Berikut adalah tampilan perancangan dari Aplikasi Pelayanan Administrasi Penduduk Desa Karang Dima Kecamatan Labuhan Badas :

\subsubsection{Halaman Login}

Halaman Login Aplikasi Pelayanan Administrasi Penduduk sebagai berikut:

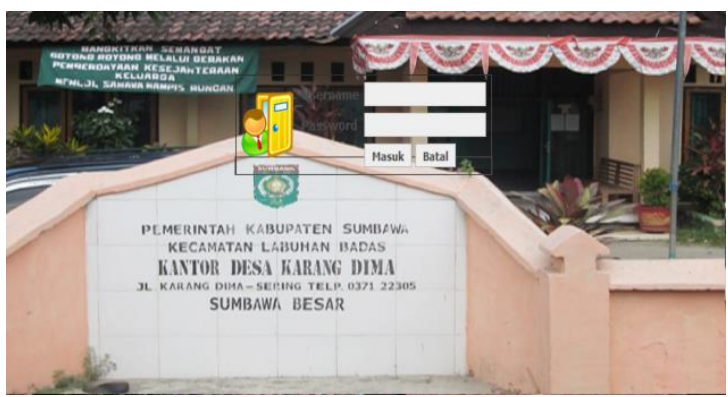

Gambar 4.11 Halaman login

Pada halaman login ini Admin atau staf Desa yang memiliki hak akses dapat memasukkan username dan password nya yang telah dibuat sebelumnya sehingga dapat mengakses kedalam aplikasi.

\subsubsection{Halaman Buat Surat}

Halaman menu membuat surat Aplikasi Pelayanan Administrasi Penduduk seperti berikut :

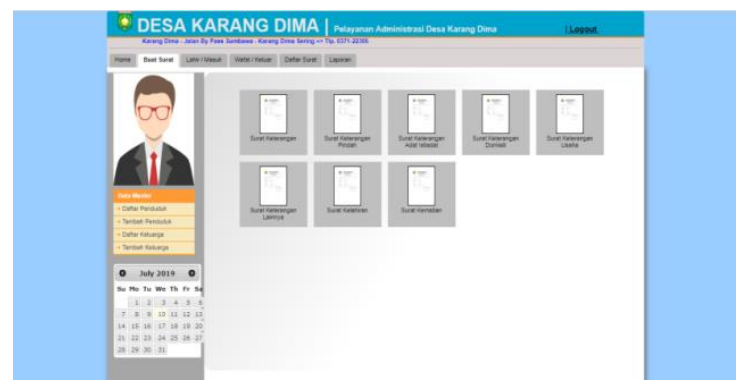

\section{Gambar 4.12 Halaman buat surat}

Pada halaman membuat surat, admin dapat mengakses atau membuat surat sesuai dengan apa yang diperlukan oleh warga. Dan mengisi form data penduduk untuk kelengkapan keterangan surat sehingga surat dapat di buat dan di cetak.

\subsection{Pengujian}

Pengujian Aplikasi Pelayanan Administrasi Penduduk Berbasis Web pada Kantor Desa Karang Dimaini menggunakan metode pengujian black box. Pengujian black boxberfokus pada persyaratan fungsional perangkat lunak. 


\subsubsection{Kasus dan Hasil Pengujian}

Berikut beberapa pengujian dan hasil pengujiannya :

Tabel 4.3 Hasil Pengujian

\begin{tabular}{|c|c|c|c|}
\hline $\begin{array}{l}\text { Requi } \\
\text { rment }\end{array}$ & $\begin{array}{l}\text { Skenario } \\
\text { uji }\end{array}$ & $\begin{array}{l}\text { Hasil yang } \\
\text { diharakan }\end{array}$ & $\begin{array}{l}\text { Hasil } \\
\text { pengujian }\end{array}$ \\
\hline \multirow[b]{2}{*}{ Login } & $\begin{array}{l}\text { Input } \\
\text { login (jika } \\
\text { benar) }\end{array}$ & $\begin{array}{l}\text { Tampil } \\
\text { halaman } \\
\text { admin }\end{array}$ & \multirow[b]{2}{*}{ Sesuai } \\
\hline & $\begin{array}{l}\text { Input } \\
\text { login } \\
\text { (jika } \\
\text { salah) }\end{array}$ & $\begin{array}{l}\text { Mengulang } \\
\text { tampilan } \\
\text { login }\end{array}$ & \\
\hline \multirow[b]{2}{*}{$\begin{array}{l}\text { Buat } \\
\text { Surat }\end{array}$} & $\begin{array}{l}\text { Isi form } \\
\text { surat } \\
\text { (jika } \\
\text { Benar) }\end{array}$ & $\begin{array}{l}\text { Surat dapat } \\
\text { disimpan } \\
\text { dan dicetak }\end{array}$ & \multirow[b]{2}{*}{ Sesuai } \\
\hline & $\begin{array}{l}\text { Isi form } \\
\text { surat } \\
\text { (jika } \\
\text { Salah) }\end{array}$ & $\begin{array}{l}\text { Cancel } \\
\text { cetak surat } \\
\text { maka } \\
\text { kembali ke } \\
\text { menu buat } \\
\text { surat }\end{array}$ & \\
\hline
\end{tabular}

\section{KESIMPULAN}

Dari hasil analisis dan perancangan aplikasi yang telah dilakukan maka dapat diambil kesimpulan bahwa Aplikasi Pelayanan Administrasi Desa Karang Dima Berbasis Web telah selesai dibangun menggunakan bahasa pemrograman PHP, Javascript dan database MySql. Dengan adanya aplikasi ini pihak desa dapat menyelesaikan masalah pelayanan Administrasi, proses yang cukup mudah, dan penyiapan berkas syarat yang banyak bisa diantisipasi sehingga tidak menghabiskan waktu berhari-hari dalam proses pembuatan surat dan urusan administrasi lainya.

\section{DAFTAR PUSTAKA}

[1] A. S., Rosa dan Shalahuddin, M, 2018. "Rekayasa Perangkat Lunak Terstruktur dan Berorientasi Objek”. Bandung: Informatika Bandung.

[2] Fathul Mubarak Muhammad. (2017). Aplikasi Pelaporan Pelayanan Publik Berbasis Android. Teknik Informatika.

[3] Kurniawan Dodik. 2017. "Rancang Bangun Sistem Informasi Pelayanan Administrasi Penduduk Pada Kantor Desa Kasreman Kecamatan Kandangan Kabupaten Kediri", Universitas Nusantara PGRI Kediri.

[4] Mustaqbal, M Sidi., Firdaus, Reori Fajri., \& Rahmadi, Hendra. (2015). "Pengujan Aplikasi Menggunakan Black Box Testing
Boundary Value Analysis". Jurnal Ilmiah Teknologi Informasi Terapan. Vol.1 No.3. Hlm.34. 